\title{
Optimasi Suhu Hidrolisis dan Konsentrasi Asam Sulfat dalam Pembuatan Nanoselulosa Berbahan Dasar Serat Batang Pisang Kepok (Musa acuminata $x$ balbisiana)
}

\author{
Optimization of Hydrolysis Temperature and Sulfuric Acid Concentration in the Making of \\ Nanocellulose Based on Kepok Banana Pseudostem Fiber (Musa acuminata x balbisiana)
}

\author{
Halimatuddahliana Nasution*, Elsworth, Fenny Wijaya \\ Departemen Teknik Kimia, Fakultas Teknik, Universitas Sumatera Utara, Jalan Almamater Kampus USU, \\ Medan, 20155, Indonesia \\ *Email: halimatuddahliana@usu.ac.id
}

\begin{abstract}
Abstrak
Penelitian ini mengkaji tentang kondisi suhu hidrolisis dan konsentrasi asam sulfat optimal dalam isolasi nanokristal selulosa (NCC) dari serat batang pisang kepok untuk mendapatkan nilai yield dan zat larut dalam air dan yang terbaik. Pada penelitian ini, serat didelignifikasi dengan menggunakan $\mathrm{NaOH}$ pada suhu $80^{\circ} \mathrm{C}$ selama 5 menit, diikuti proses bleaching dengan menggunakan $\mathrm{H}_{2} \mathrm{O}_{2}$ selama 30 menit sebanyak dua kali, dilanjutkan dengan proses hidrolisis asam dengan menggunakan $\mathrm{H}_{2} \mathrm{SO}_{4}$ selama 1 jam pada variasi suhu hidrolisis $45^{\circ} \mathrm{C}, 50^{\circ} \mathrm{C}, 55^{\circ} \mathrm{C}, 60^{\circ} \mathrm{C}$ dan variasi konsentrasi asam sulfat 40\%, 45\%, 50\% dan 55\%, dan diultrasonikasi selama 5 menit. Hasil analisis Transmission Electron Microscopy menunjukkan NCC yang terisolasi berukuran $125-144 \mathrm{~nm}$. Nilai yield NCC tertinggi diperoleh pada variasi suhu hidrolisis $60^{\circ} \mathrm{C}$ dan konsentrasi asam sulfat $55 \%$ sebesar $26,75 \%$ yang menunjukkan peningkatan yield seiring dengan peningkatan variabel konsentrasi asam sulfat dan suhu hidrolisis. Nilai zat larut dalam air terendah diperoleh sebesar $0 \%$ yang menunjukkan kemurnian selulosa yang digunakan dalam mengisolasi NCC.
\end{abstract}

Kata kunci: nanokristal selulosa, serat batang pisang kepok, hidrolisis asam, yield, kelarutan dalam air

\begin{abstract}
This research aims to investigate the optimal hydrolysis temperature and sulfuric acid $\left(\mathrm{H}_{2} \mathrm{SO}_{4}\right)$ concentration in isolating nanocrystalline cellulose (NCC) from kepok banana pseudostem fiber with the best yield and water solubility. In this research, cellulose fiber was delignified with $\mathrm{NaOH}$ at $80^{\circ} \mathrm{C}$ for 5 minutes, then followed by bleaching with hydrogen peroxide $\left(\mathrm{H}_{2} \mathrm{O}_{2}\right)$ for 30 minutes twice. NCC was isolated through acid hydrolysis with $\mathrm{H}_{2} \mathrm{SO}_{4}(40 \%, 45 \%, 50 \%, 55 \% \mathrm{v} / \mathrm{v})$ at $45{ }^{\circ} \mathrm{C}, 50{ }^{\circ} \mathrm{C}, 55{ }^{\circ} \mathrm{C}$, $60{ }^{\circ} \mathrm{C}$ for 1 hour and ultrasonicated for 5 minutes. NCC crystal was then characterized through Transmission Electron Microscopy (TEM), and water solubility. TEM analysis showed the isolated NCC has a measured length of $125-144 \mathrm{~nm}$. The highest NCC yield was obtained at $60^{\circ} \mathrm{C}$ and $55 \%$ $\mathrm{H}_{2} \mathrm{SO}_{4}$ at $26.75 \%$. This analysis showed that $\mathrm{NCC}$ yield increases with increasing $\mathrm{H}_{2} \mathrm{SO}_{4}$ concentration and hydrolysis temperature. The lowest water solubility obtained is $0 \%$, which shows the purity of the cellulose used to isolate NCC.
\end{abstract}

Keywords: nanocrystalline cellulose, kepok banana fiber, acid hydrolysis, yield, water solubility

\section{Pendahuluan}

Pada tahun 2014, produksi pisang di Indonesia mencapai 7.008.407 ton [1]. Buah dan daun pisang merupakan bagian dari pisang yang umum dimanfaatkan, namun produksi pisang yang melimpah menandakan limbah batang pisang yang banyak pula. Limbah batang pisang yang dibiarkan begitu saja dapat menyebabkan ketidakseimbangan ekosistem dan menyebabkan petani sulit memanen buah yang telah matang [2][3]. Pembakaran limbah batang pisang yang bertumpuk di alam terbuka dapat menyebabkan masalah lingkungan yang serius [3].
Untuk mengatasi masalah tersebut, salah satu upaya yang telah dilakukan untuk memanfaatkan limbah batang pisang tersebut yaitu menjadikannya pakan ternak alternatif [4]. Dalam penelitian ini, serat dari batang pisang dimanfaatkan sebagai bahan baku pembuatan nanokristal selulosa (NCC) karena kandungan selulosanya yang tinggi. Serat batang pisang mengandung 50\% selulosa, $17 \%$ lignin, dan $4 \%$ abu, namun komposisi dari serat batang pisang dapat bervariasi [5].

Salah satu metode pembuatan nanokristal selulosa adalah hidrolisis asam, dimana selulosa 
diisolasi dari suatu bahan yang mengandung selulosa melalui proses delignifikasi terlebih dahulu, kemudian diikuti dengan reaksi hidrolisis menggunakan suatu asam kuat seperti asam sulfat. Namun, konsentrasi asam dan suhu hidrolisis mempengaruhi kualitas nanoselulosa yang dihasilkan. Menurut studi literatur yang telah dilakukan, konsentrasi asam yang terlalu tinggi akan menyebabkan kehancuran total selulosa [6] sedangkan konsentrasi asam yang terlalu rendah tidak dapat mempenetrasi matriks selulosa untuk memulai reaksi hidrolisis [7], sementara suhu yang terlalu tinggi sulit dikendalikan dan suhu yang terlalu rendah membutuhkan waktu yang lebih lama [8]. Untuk mengetahui kondisi operasi yang tepat, perlu dilakukan kajian terhadap konsentrasi asam dan suhu operasi yang optimal untuk menghasilkan nanokristal selulosa dengan yield yang tertinggi.

\section{Teori}

Serat batang pisang merupakan serat lignoselulosa yang didapat dari bagian pseudo-stem pada suatu tanaman pisang dan merupakan produk limbah dari pengolahan pisang yang tidak termanfaatkan atau hanya termanfaatkan sebagian. Serat batang pisang juga memiliki sifat-sifat seperti kekuatan yang tinggi, ringan, sifat ketahanan api, kemampuan penyerapan air yang tinggi dan dapat terdegradasi secara biologis [9]. Tabel 1 menunjukkan komposisi kimia dari serat batang pisang [10].

Tabel 1. Komposisi Kimia Serat Batang Pisang

\begin{tabular}{|l|l|}
\hline \multicolumn{1}{|c|}{ Komponen } & \multicolumn{1}{c|}{ Kadar (\%) } \\
\hline Air & 96,7 \\
\hline Selulosa & 46,3 \\
\hline Hemiselulosa & 12,5 \\
\hline Lignin & 15,8 \\
\hline Abu & 10,7 \\
\hline Pektin & 3,9 \\
\hline
\end{tabular}

Istilah nanokristal selulosa (nanocellulose crystalline (NCC)) digunakan untuk menyebut nanopartikel selulosa kristal memanjang yang berbentuk seperti tongkat. NCC memiliki potensi tinggi sebagai agen penguat dalam nanokomposit karena ukurannya dan kemungkinan untuk memodifikasi permukaannya secara kimia. NCC konvensional memiliki modulus dan kekakuan yang tinggi yang dapat mencapai $134 \mathrm{GPa}$. Struktur kristal NCC menunjukkan kekuatan tensil dari 0,8 hingga 10 GPa [11].

Secara umum, metode-metode yang digunakan untuk isolasi NCC terbagi menjadi 2 jenis, yaitu mekanis [12][13][14][15] dan kimia [16][17][18][19] Isolasi NCC secara mekanis meliputi homogenisasi yang melibatkan serat dipaksakan melewati suatu bukaan yang sangat kecil dengan menggunakan piston pada tekanan tinggi, penggilingan yang melibatkan serat dilumatkan diantara 2 roda penggiling yang berputar pada kecepatan tinggi, cryocrushing dimana serat selulosa yang beku dihancurkan, dan sonikasi dimana NCC dihasilkan melalui aplikasi gaya hidrodinamis yang dihasilkan oleh alat ultrasound pada serat bahan baku. Metode pembuatan NCC secara kimia yang utama dilakukan yaitu hidrolisis asam, dimana serat dimurnikan terlebih dahulu untuk menghilangkan komponen-komponen yang bukan merupakan selulosa, kemudian diikuti dengan hidrolisis asam untuk memisahkan bagian amorf dan melepaskan NCC [20].

Pada penelitian ini, metode yang digunakan untuk mengisolasi NCC yaitu metode hidrolisis asam, dimana selulosa pertama diisolasi dari serat batang pisang melalui proses pelepasan lignin yang disebut delignifikasi, yang dilakukan dengan perlakuan dengan alkali, yaitu $\mathrm{NaOH}$ dan diikuti dengan perlakuan pemutihan (bleaching) dengan menggunakan $\mathrm{H}_{2} \mathrm{O}_{2}$. Selanjutnya selulosa dikonversikan menjadi nanokristal selulosa melalui hidrolisis asam dengan menggunakan $\mathrm{H}_{2} \mathrm{SO}_{4}$. Asam klorida $(\mathrm{HCl})$ dan $\mathrm{H}_{2} \mathrm{SO}_{4}$ merupakan dua jenis asam yang biasa digunakan untuk hidrolisis asam. $\mathrm{HCl}$ memberikan nanokristal yang mendekati netral dengan kelarutan yang terbatas dalam air, sedangkan $\mathrm{H}_{2} \mathrm{SO}_{4}$ memberikan produk yang lebih stabil pada jarak $\mathrm{pH}$ yang luas [21]. Metode ini mudah dan cepat untuk menghasilkan nanokristal selulosa yang memiliki sifat-sifat yang lebih baik [22].

\section{Metodologi Penelitian Bahan dan Peralatan}

Bahan yang digunakan dalam penelitian ini yaitu serat dari pelepah tengah batang pisang yang tidak terlalu keras namun tidak terlalu lembut sebagai bahan baku persiapan nanokristal selulosa, asam sulfat $\left(\mathrm{H}_{2} \mathrm{SO}_{4}\right)$ sebagai agen penghidrolisis, hidrogen peroksida $\left(\mathrm{H}_{2} \mathrm{O}_{2}\right)$ sebagai agen bleaching dan natrium hidroksida $(\mathrm{NaOH})$ sebagai agen delignifikasi.

Peralatan yang digunakan akan dalam penelitian ini adalah: Corong pemisah, hot plate, indikator universal, kertas Whatman no.1, membran dialisis, neraca elektrik, oven, stirrer, ultrasonic bath, wadah dan water bath.

\section{Penyiapan Alfa Selulosa}

Sebanyak $15 \mathrm{~g}$ serat batang pisang yang telah dipotong hingga menjadi serbuk direndam selama 5 menit dalam $10 \%(\mathrm{~b} / \mathrm{v}) \mathrm{NaOH}$ dengan rasio serat : $\mathrm{NaOH}$ sebesar $1: 20$ yang telah dipanaskan hingga suhu $80^{\circ} \mathrm{C}$ dengan pengadukan konstan. Proses bleaching dilakukan dengan menambahkan $60 \mathrm{ml}$ $\mathrm{H}_{2} \mathrm{O}_{2} 30 \%$ (v/v) kedalam campuran dan diaduk selama 30 menit. Tahap bleaching diulang dua kali hingga menghasilkan campuran sebanyak $420 \mathrm{ml}$, yang diaduk selama 30 menit pada suhu $80^{\circ} \mathrm{C}$. Alfa selulosa 
kemudian difiltrasi menggunakan kertas Whatman no.1 dan dicuci dengan menggunakan air hingga mencapai $\mathrm{pH}$ netral. Selulosa yang diperoleh kemudian dikeringkan dibawah sinar matahari hingga mencapai berat konstan.

\section{Analisa Yield}

Yield alfa selulosa dan nanokristalin selulosa dihitung dengan menggunakan rumus:

$$
\text { Yield }(\%)=\frac{\mathrm{W}_{\mathrm{p}}}{\mathrm{W}_{1}} \times 100 \%
$$

Dimana:

$\mathrm{W}_{\mathrm{p}}=$ berat produk

$\mathrm{W}_{\mathrm{I}}=$ berat bahan baku

\section{Analisa Zat Larut dalam Air}

Sebanyak 0,5 g sampel nanokristalin selulosa dicampurkan dengan $80 \mathrm{ml}$ air distilasi selama 10 menit dengan pengadukan dan kemudian disaring dengan menggunakan kertas Whatman no.1. Campuran kemudian dikeringkan diatas water bath pada suhu $100-105^{\circ} \mathrm{C}$ selama 1 jam. Sampel yang telah dikeringkan dibandingkan dengan berat awal sampel. Kadar zat larut dalam air dihitung dengan persamaan:

$$
\text { Zat larut dalam air }(\%)=\frac{\mathrm{W}_{1}-\mathrm{W}_{2}}{\mathrm{~W}_{1}}
$$

Dimana:

$$
\begin{aligned}
& \mathrm{W}_{1}=\text { berat sampel awal } \\
& \mathrm{W}_{2}=\text { berat sampel setelah pengeringan }
\end{aligned}
$$

\section{Hasil}

\section{Transmission Electron Microscopy (TEM)}

Hasil analisa TEM ditunjukkan pada Gambar 1. Gambar tersebut menunjukkan hasil nanokristal selulosa (NCC) yang memiliki morfologi jarum dengan panjang rata-rata $125,012 \mathrm{~nm}$ dan lebar ratarata $10,448 \mathrm{~nm}$. Hasil ini sesuai dengan hasil penelitian Pereira, dkk., 2014 [23], dan Zheng, dkk., 2019 [24], yang menyatakan bahwa nanokristal selulosa memiliki bentuk menyerupai batang (rod) / jarum (needle) dan memiliki ukuran geometri dalam range $100 \mathrm{~nm}$ hingga $1-2 \mu \mathrm{m}$, tergantung dari sumber selulosanya.

Nanokristal selulosa yang berbentuk seperti batangan (rod) diperoleh melalui proses hidrolisis asam dengan menghilangkan bagian amorf dari rantai selulosa [25]. Hal ini dikarenakan bagian amorf dari selulosa lebih mudah berinteraksi dengan asam dibandingkan dengan bagian kristalinnya yang akan menyebabkan degradasi dari bagian amorf tersebut dan menyisakan bagian kristalinnya [26].

Menurut penelitian Vanhatalo dan Dahl, 2014 [27], peningkatan suhu hidrolisis, konsentrasi asam dan waktu hidrolisis hingga suatu batasan tertentu dapat memperkecil ukuran kristal dari selulosa namun memberikan nilai yield yang lebih rendah.

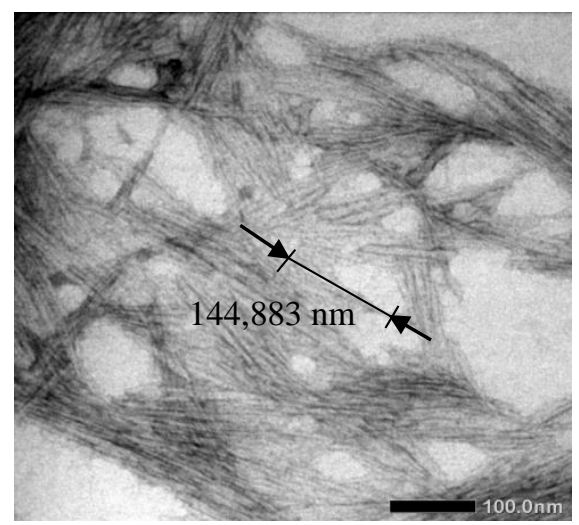

Gambar 1. Analisa TEM dari NCC berbahan dasar serat batang pisang kepok

\section{Analisa Yield}

Hasil yield alfa selulosa dari delignifikasi dan pemutihan (bleaching) serat batang pisang menggunakan $\mathrm{NaOH}$ dan $\mathrm{H}_{2} \mathrm{O}_{2}$ dan isolasi NCC dari alfa selulosa melalui hidrolisis asam menggunakan $\mathrm{H}_{2} \mathrm{SO}_{4}$ ditunjukkan pada Gambar 2 dan 3 .

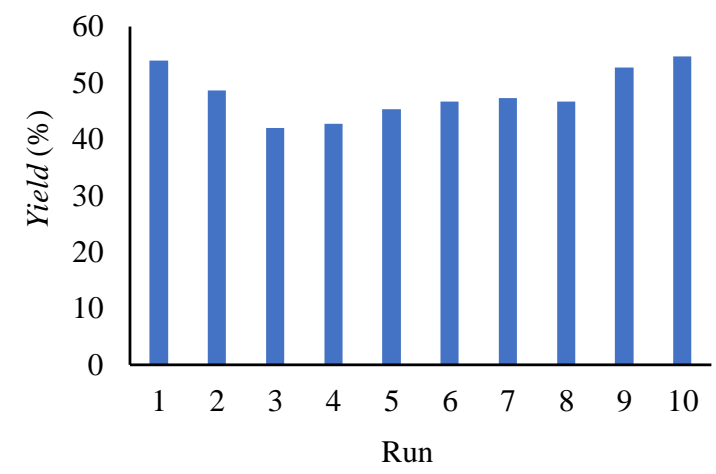

Gambar 2. Yield Alfa Selulosa dari Delignifikasi Serat Batang Pisang Kepok

Dari Gambar 2 didapat nilai yield alfa selulosa dari hasil delignifikasi serat batang pisang dengan $\mathrm{NaOH}$ selama 5 menit pada suhu $80^{\circ} \mathrm{C}$ dan bleaching dengan $\mathrm{H}_{2} \mathrm{O}_{2}$ selama 60 menit untuk 10 pengulangan, yaitu: 54, 48,67, 42, 42,67, 45,33, 46,67, 47,33, 46,67, $52,67,54,67,48,067 \%$, dengan nilai rata-rata yaitu $48,067 \%$. Hasil ini sesuai dengan teori kadar selulosa dari serat batang pisang oleh Das, dkk., 2018 [28], dan Rahman, dkk., 2018 [29], yang masing-masing menyatakan $44-54 \%$ dan $48-50 \%$. 


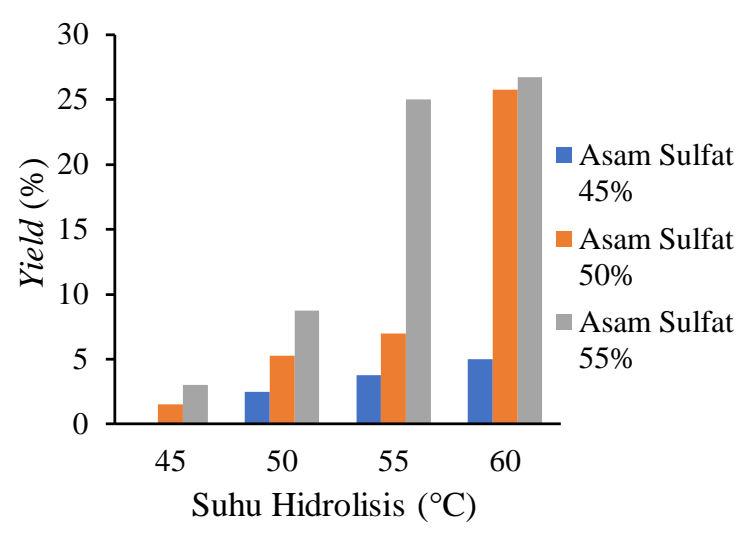

Gambar 3. Yield NCC dari Hidrolisis Asam Alfa Selulosa

Dari Gambar 3, tampak pada kondisi konsentrasi asam sulfat $40 \%$ dan suhu hidrolisis $45,50,55,60^{\circ} \mathrm{C}$ serta konsentrasi asam sulfat $45 \%$ dan suhu hidrolisis $45^{\circ} \mathrm{C}$ tidak menunjukkan adanya pembentukan gel nanokristalin selulosa. Hal ini dikarenakan kondisi minimum yang diperlukan untuk mengisolasi nanokristalin selulosa adalah dengan konsentrasi asam sulfat $45-70 \%$ pada suhu ruangan hingga $70^{\circ} \mathrm{C}$ [30][31][32][33][34]. Yield NCC tertinggi diperoleh pada suhu hidrolisis $60^{\circ} \mathrm{C}$ dan konsentrasi asam sulfat $55 \%$ dengan nilai $26,75 \%$.

Pada penelitian ini, NCC diisolasi dengan menggunakan metode hidrolisis asam. Ketika serat selulosa diperlakukan dengan asam, asam akan berdifusi pada bagian non-kristalin dari serat selulosa dan menghidrolisis ikatan glikosida. Setelah itu, ikatan glikosida lain dalam selulosa akan terhidrolisis dan akhirnya hidrolisis terjadi pada bagian pereduksi dan pada permukaan nanokristal. Hidrolisis dari grup pereduksi dan permukaan nanokristal akan menyebabkan nanokristal menjadi bermuatan tergantung asam yang digunakan [35]. NCC yang dihasilkan dari metode hidrolisis asam akan mengandung ion sulfat yang dapat memicu reaksi dehidrasi pada NCC yang dihasilkan. Ion sulfat tersebut dapat dipisahkan dari NCC melalui metode dialisis dengan menggunakan membran dialisis [36].

Salah satu faktor yang mempengaruhi yield NCC yaitu suhu reaksi. Suhu hidrolisis yang rendah membutuhkan waktu reaksi yang lebih lama untuk menghasilkan NCC yang dapat membentuk suspensi yang homogen, namun reaksi dari suhu hidrolisis yang tinggi sulit dikendalikan dikarenakan degradasi yang terlalu cepat [8].

Faktor lain yang mempengaruhi sifat dari nanokristalin selulosa adalah konsentrasi asam, dimana asam yang biasa digunakan adalah asam sulfat. Konsentrasi asam yang terlalu tinggi akan menyebabkan reaksi kekurangan air, sedangkan konsentrasi asam yang terlalu rendah tidak akan dapat memiliki kemampuan penetrasi matriks selulosa yang cukup. Konsentrasi asam yang rendah tidak akan mampu melewati hingga bagian dalam dari selulosa, sehingga hidrolisis dari bagian amorf selulosa tidak akan berjalan efektif dan menurunkan yield dari nanokristalin selulosa [7].

Faktor terakhir yang mempengaruhi yield dari nanokristalin selulosa ialah perlakuan ultrasonikasi setelah hidrolisis asam. Ultrasonikasi memecah struktur serat selulosa melalui gaya hidrodinamik dari gelombang ultrasonic yang dihasilkan oleh alat ultrasound. Hal ini dapat memecah ikatan hidrogen antarserat sehingga melepas nanokristal selulosa [37].

\section{Analisa Zat Larut dalam Air}

Hasil analisis zat larut dalam air pada NCC yang diperoleh ditunjukkan pada Gambar 4.

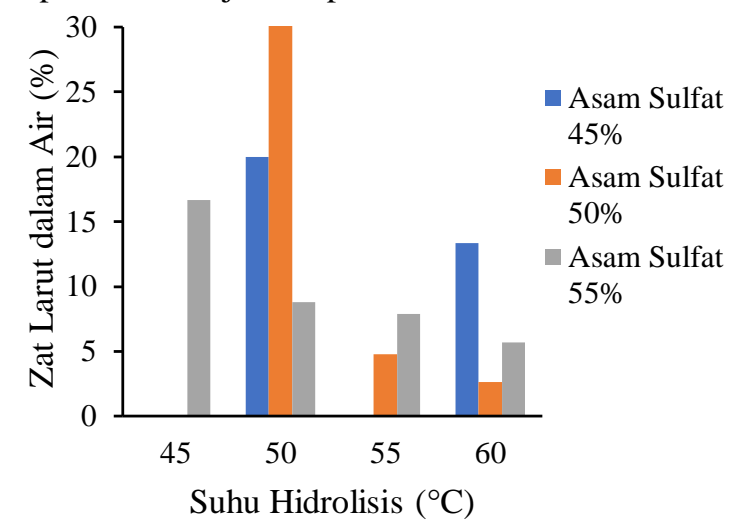

\section{Gambar 4. Hasil Analisa Zat Larut dalam Air}

Dari Gambar 4, nilai zat larut dalam air terendah yang diperoleh yaitu $0 \%$ sementara nilai zat larut dalam air tertinggi yang diperoleh yaitu 33,33\% pada suhu hidrolisis $50^{\circ} \mathrm{C}$ dan konsentrasi asam sulfat $50 \%$. Hal ini dikarenakan selulosa yang digunakan masih mengandung serat alami berupa pektin, gum, dan mucilage [38].

Perlakuan hidrolisis asam dengan menggunakan asam sulfat pada sampel yang masih mengandung residu pektin dapat menyebabkan asam untuk berikatan silang dengan ikatan rantai molekul pektin [39].

Suhu hidrolisis dan konsentrasi asam juga dapat mempengaruhi ikatan pektin yang terbentuk. Suhu hidrolisis yang semakin tinggi akan meningkatkan ikatan pektin yang terbentuk hingga $50^{\circ} \mathrm{C}$ [40]. Sementara itu, konsentrasi asam yang terlalu tinggi akan menyebabkan degradasi pektin [41]. Hal ini dapat menjelaskan nilai zat larut dalam air pada nanokristalin selulosa yang semakin menurun seiring dengan meningkatnya suhu hidrolisis dan konsentrasi asam.

\section{Kesimpulan}

NCC yang terisolasi memiliki bentuk menyerupai jarum dengan panjang rata-rata 125,012 $\mathrm{nm}$ dan lebar rata-rata $10,448 \mathrm{~nm}$. Kondisi hidrolisis terbaik diperoleh pada suhu $65^{\circ} \mathrm{C}$ dan konsentrasi asam sulfat $55 \%$. Hal ini didukung oleh nilai yield 
yang tertinggi, yaitu 26,75\% dan nilai zat larut yang cukup rendah, yaitu $5,71 \%$.

\section{Daftar Pustaka}

[1] T. K. Putri et al., "Pemanfaatan jenis-jenis pisang (banana dan plantain) lokal Jawa Barat berbasis produk sale dan tepung," Kultivasi, vol. 14, no. 2, pp. 63-70, 2015.

[2] A. Mohiuddin, M. K. Saha, M. S. Hossian, and A. Ferdoushi, "Usefulness of Banana (Musa paradisiaca) Wastes in Manufacturing of Bio-products: A Review," Agric., vol. 12, no. 1, pp. 148-158, 2014.

[3] B. S. Padam, H. S. Tin, F. Y. Chye, and M. I. Abdullah, "Banana by-products: an underutilized renewable food biomass with great potential," J. Food Sci. Technol., vol. 51, no. 12, pp. 3527-3545, 2014.

[4] I. Sutowo, T. Adelina, and D. Febrina, "Kualitas Nutrisi Silase Limbah Pisang (Batang Dan Bonggol) Dan Level Molases Yang Berbeda Sebagai Pakan Alternatif Ternak Ruminansia," J. Peternak., vol. 13, no. 2, p. 41, 2017.

[5] N. Reddy and Y. Yang, "Innovative biofibers from renewable resources," Innov. Biofibers from Renew. Resour., pp. 1-454, 2015.

[6] V. Barbash, O. Yashchenko, and A. Kedrovska, "Preparation and Properties of Nanocellulose from Peracetic Flax Pulp," J. Sci. Res. Reports, vol. 16, no. 1, pp. 1-10, 2017.

[7] C. P. Chang, I. C. Wang, K. J. Hung, and Y. S. Perng, "Preparation and characterization of nanocrystalline cellulose by acid hydrolysis of cotton linter," Taiwan J. For. Sci., vol. 25, no. 3, pp. 251-264, 2010.

[8] X. Li, E. Ding, and G. Li, "A Method of Preparing Spherical Nano-Crystal Cellulose with Mixed Crystalline Forms of Cellulose I and II," Chinese J. Polym. Sci., vol. 19, no. 3, pp. 291-296, 2001.

[9] R. Bhatnagar, G. Gupta, and S. Yadav, "A Review on Composition and Properties of Banana Fibers," Int. J. Sci. Eng. Res., vol. 6, no. 5, pp. 143-148, 2015.

[10] J. S. Jayaprabha, M. Brahmakumar, and V. B. Manilal, "Banana pseudostem characterization and its fiber property evaluation on physical and bioextraction," $J$. Nat. Fibers, vol. 8, no. 3, pp. 149-160, 2011.

[11] N. A. Rosli, I. Ahmad, and I. Abdullah, "Isolation and characterization of cellulose nanocrystals from agave angustifolia fibre," BioResources, vol. 8, no. 2, pp. 1893-1908, 2013.

[12] S. N. Pentakota, V. V. S. Prasad, K. Ramji, and G. Pusty, "Synthesis of bio-degradable banana nanofibers," Ijitr, vol. 2, no. 1, pp. 730-734, 2014.

[13] M. Rahimi Kord Sofla, R. J. Brown, T.
Tsuzuki, and T. J. Rainey, "A comparison of cellulose nanocrystals and cellulose nanofibres extracted from bagasse using acid and ball milling methods," Adv. Nat. Sci. Nanosci. Nanotechnol., vol. 7, no. 3, 2016.

[14] A. G. De Souza, F. S. Kano, J. J. Bonvent, and D. Dos Santos Rosa, "Cellulose nanostructures obtained from waste paper industry: A comparison of acid and mechanical isolation methods," Mater. Res., vol. 20, pp. 209-214, 2017.

[15] B. Wang and M. Sain, "Dispersion of soybean stock-based nanofiber in plastic matrix," ACS Symp. Ser., vol. 938, pp. 187-208, 2006.

[16] M. Mariño, L. L. Da Silva, N. Durán, and L. Tasic, "Enhanced materials from nature: Nanocellulose from citrus waste," Molecules, vol. 20, no. 4, pp. 5908-5923, 2015.

[17] P. Nascimento, R. Marim, G. Carvalho, and S. Mali, "Nanocellulose produced from rice hulls and its effect on the properties of biodegradable starch films," Mater. Res., vol. 19, no. 1, pp. 167-174, 2016.

[18] N. H. A. Rahman, B. W. Chieng, N. A. Ibrahim, and N. A. Rahman, "Extraction and characterization of cellulose nanocrystals from tea leaf waste fibers," Polymers (Basel)., vol. 9, no. 11, pp. 1-11, 2017.

[19] H. Tibolla, F. M. Pelissari, J. T. Martins, A. A. Vicente, and F. C. Menegalli, "Cellulose nanofibers produced from banana peel by chemical and mechanical treatments: Characterization and cytotoxicity assessment," Food Hydrocoll., vol. 75, pp. 192-201, 2018.

[20] H. Kargarzadeh, M. Ioelovich, I. Ahmad, S. Thomas, and A. Dufresne, "Methods for Extraction of Nanocellulose from Various Sources," Handb. Nanocellulose Cellul. Nanocomposites, pp. 1-49, 2017.

[21] M. T. Islam, M. M. Alam, A. Patrucco, A. Montarsolo, and M. Zoccola, "Preparation of nanocellulose: A review," AATCC J. Res., vol. 1, no. 5, pp. 17-23, 2014.

[22] W. T. Wulandari, A. Rochliadi, and I. M. Arcana, "Nanocellulose prepared by acid hydrolysis of isolated cellulose from sugarcane bagasse," in IOP Conference Series: Materials Science and Engineering, 2016, vol. 107, no. 1.

[23] A. L. S. Pereira et al., "Improvement of polyvinyl alcohol properties by adding nanocrystalline cellulose isolated from banana pseudostems," Carbohydr. Polym., vol. 112, pp. 165-172, 2014.

[24] D. Zheng, Y. Zhang, Y. Guo, and J. Yue, "Isolation and Characterization of Nanocellulose with a Novel Shape from Walnut (Juglans Regia L.) Shell Agricultural Waste," Polymers (Basel)., vol. 11, no. 7, pp. 
$1-14,2019$.

[25] A. H. Bhat, Y. K. Dasan, I. Khan, H. Soleimani, and A. Usmani, "Application of nanocrystalline cellulose: Processing and biomedical applications," Cellul. Nanofibre Compos. Prod. Prop. Appl., no. November, pp. 215-240, 2017.

[26] H. Xie, H. Du, X. Yang, and C. Si, "Recent Strategies in Preparation of Cellulose Nanocrystals and Cellulose Nanofibrils Derived from Raw Cellulose Materials," Int. J. Polym. Sci., vol. 2018, 2018.

[27] K. M. Vanhatalo and O. P. Dahl, "Effect of Mild Acid Hydrolysis Parameters on Properties of Microcrystalline Cellulose," BioResources, vol. 9, no. 3, pp. 4729-4740, 2014.

[28] S. Das, M. Rahman, and M. Hasan, "PhysicoMechanical Properties of Pineapple Leaf and Banana Fiber Reinforced Hybrid Polypropylene Composites: Effect of Fiber Ratio and Sodium Hydroxide Treatment," IOP Conf. Ser. Mater. Sci. Eng., vol. 438, no. $1,2018$.

[29] M. Rahman, S. Das, and M. Hasan, "Mechanical properties of chemically treated banana and pineapple leaf fiber reinforced hybrid polypropylene composites," $A d v$. Mater. Process. Technol., vol. 4, no. 4, pp. 527-537, 2018.

[30] Y. Habibi, L. A. Lucia, and O. J. Rojas, "Cellulose nanocrystals: Chemistry, selfassembly, and applications," Chem. Rev., vol. 110, no. 6, pp. 3479-3500, 2010.

[31] M. Ioelovich, "Study of Cellulose Interaction with Concentrated Solutions of Sulfuric Acid," ISRN Chem. Eng., vol. 2012, pp. 1-7, 2012.

[32] M. Ioelovich and A. Leykin, "Microcrystalline Cellulose : Nano-Structure Formation," Cellul. Chem. Technol., vol. 40, no. 5, pp. 313-317, 2006.

[33] M. Ioelovich, "Cellulose as a nanostructured polymer: A short review," BioResources, vol. 3, no. 4, pp. 1403-1418, 2008.

[34] L. Yang and J. R. Arthur, "Cellulose Nano Whiskers as a Reinforcing Filler in Polyurethanes," Adv. Divers. Ind. Appl. Nanocomposites, pp. 17-32, 2011.

[35] M. Börjesson and G. Westman, "Crystalline Nanocellulose - Preparation, Modification, and Properties," in Cellulose - Fundamental Aspects and Current Trends, 2015, pp. 159191.

[36] H. Yu, Z. Qin, B. Liang, N. Liu, Z. Zhou, and L. Chen, "Facile extraction of thermally stable cellulose nanocrystals with a high yield of 93\% through hydrochloric acid hydrolysis under hydrothermal conditions," J. Mater. Chem. A, vol. 1, no. 12, pp. 3938-3944, 2013.
[37] Z. Hu, R. Zhai, J. Li, Y. Zhang, and J. Lin, "Preparation and Characterization of Nanofibrillated Cellulose from Bamboo Fiber via Ultrasonication Assisted by Repulsive Effect," Int. J. Polym. Sci., vol. 2017, 2017.

[38] D. Dhingra, M. Michael, H. Rajput, and R. T. Patil, "Dietary fibre in foods: A review," $J$. Food Sci. Technol., vol. 49, no. 3, pp. 255266, 2012.

[39] H. M. Wang, R. Postle, R. W. Kessler, and W. Kessler, "Removing Pectin and Lignin During Chemical Processing of Hemp for Textile Applications," Text. Res. J., vol. 73, no. 8, pp. 664-669, 2003.

[40] S. Y. Chan and W. S. Choo, "Effect of extraction conditions on the yield and chemical properties of pectin from cocoa husks," Food Chem., vol. 141, no. 4, pp. 3752-3758, 2013.

[41] G. O. Locatelli, L. Finkler, and C. L. L. Finkler, "Comparison of acid and enzymatic hydrolysis of pectin, as inexpensive source to cell growth of Cupriavidus necator," $A n$. Acad. Bras. Cienc., vol. 91, no. 2, p. e20180333, 2019. 